\title{
Histopathological Study of Endoscopic Biopsies
}

\author{
Rupendra Thapa, ${ }^{1,2}$ Mamta Lakhey, ${ }^{1,2}$ Pradeep Kumar Yadav, ${ }^{2}$ Prakash Kandel, ${ }^{3}$ Choodamani Aryal, ${ }^{3}$ \\ Kamana Subba ${ }^{4}$
}

'Department of Pathology, Kathmandu Medical College, Sinamangal, Kathmandu, ${ }^{2}$ Medicare National Hospital and Research Centre, Chabahil, Kathmandu, Nepal, ${ }^{3}$ xenoMED Foundation, Kathmandu, Nepal, ${ }^{4}$ Bracknell, Berkshire, UK.

\section{ABSTRACT}

Introduction: Diseases of upper gastrointestinal tract are responsible for a great deal of morbidity and mortality. The histopathological study of endoscopic biopsies permits exact diagnosis for further management. The aim of this study is to find out the histopathological pattern of endoscopic biopsy.

Methods: A descriptive study was conducted in consecutive endoscopic gastric biopsies in a Hospital over a period of one year. The patient of all ages and both sexes who underwent gastric biopsy during the study period was included.

Results: Endoscopic biopsies were studied on patients of age ranging from 20 years female to 84 years male. The histopathology revealed non-neoplastic lesions 54 (67.5\%) and neoplastic lesions 26 $(32.5 \%)$. Most common non-neoplastic lesion noted was mild chronic gastritis $22(27.5 \%)$ followed by chronic active gastritis $15(18.75 \%)$ while H. pylori was present in $13(16.25 \%)$ and absent in $2(2.5 \%)$.

Conclusions: Mild chronic gastritis was the commonest lesion noted in non-neoplastic lesions and adenocarcinoma was the commonest neoplastic lesion in the endoscopic gastric biopsies.

Keywords: biopsy; endoscopy; gastritis; histopathological.

\section{INTRODUCTION}

Diseases of upper gastrointestinal tract are responsible for a great deal of morbidity and mortality. The term gastritis should be reserved for histologically documented inflammation of the gastric mucosa. Gastritis is simply defined as inflammation of the gastric mucosa. Inflammation may be predominantly acute, with neutrophilic inflammation, or chronic, with lymphocytes and/or plasma cells predominating and associated intestinal metaplasia and atrophy. ${ }^{1}$ Gastritis has been classified in several ways, which differ from one country to another, sometimes from one department to another and even within a single institution, depending upon the investigator concerned. In order to avoid confusion, Sydney system has been proposed for the microscopic reporting of gastritis. ${ }^{2}$
The upper gastrointestinal flexible fibropticendoscope was first used in 1968 and proved to be a major breakthrough in the diagnosis of oesophago- gastro duodenal lesions. ${ }^{3}$ The histopathological study of endoscopic biopsies permits exact diagnosis for further management. It also provides an opportunity to see Helicobacter pylori status and plans for specific medical or surgical therapy. It can detect the early stages of the neoplastic lesions and may prevent the progression of these lesions to invasive cancer. ${ }^{4,5}$ The aim of this study is to find out the histopathological pattern of endoscopic biopsy.

Correspondence: Dr. Rupendra Thapa, Department of Pathology, Kathmandu Medical College, Sinamangal, Kathmandu, Nepal. Email: rup432@gmail.com, Phone: 9841201342. 
Thapa et al. Histopathological Study of Endoscopic Biopsies

\section{METHODS}

A descriptive study was conducted in consecutive endoscopic gastric biopsies in the Department of Pathology of Medicare National Hospital and Research Centre from $1^{\text {st }}$ April 2011 to $30^{\text {th }}$ April 2012. Patient of all ages and both sexes having undergone gastric biopsy were included in the study. The biopsy specimens were fixed in $10 \%$ formalin and routinely processed. Paraffin wax sections were cut at 4 micron thickness and stained with Haematoxylin and Eosin (H\&E) stain and with special stain Giemsa when needed. All these biopsies were graded morphologically according to updated Sydney System. Majority of the biopsies were taken from different part of the stomach as per the recommendation (Sydney System). Activity was accounted by the presence of polymorph neutrophils in the lamina propria, within the epithelium and within the foveolarlumen. ${ }^{2}$ Thetumors were classified according to the WHO classification of gastric tumors. The data were entered into Microsoft Excel 2010 and descriptive analysis was done.

\section{RESULTS}

In the present study, endoscopic biopsies were studied on patients of age ranging from 20 years female to 84 years male. Among the non-neoplastic lesions age ranged from 23 years to 84 years and in neoplastic lesions 45 to 77 years. A slight high frequency of the gastric disease in males with male to female ratio of 1.28:1 was observed. The majority of the patients were biopsied for either gastritis or tumors of stomach. The histopathology revealed non-neoplastic lesions $54(67.5 \%)$ and neoplastic lesions 26 (32.5\%). Most common non-neoplastic lesion noted was mild chronic gastritis $22(27.5 \%)$ followed by chronic active gastritis $15(18.75 \%)$ while H.Pylori was present in $13(16.25 \%)$ and absent in $2(2.5 \%)$. Atrophy was noted in $6(7.5 \%)$ of cases of chronic active gastritis (Table1).

\begin{tabular}{|ll|}
\hline $\begin{array}{l}\text { Table 1. Distribution of cases on the basis of mor- } \\
\text { phology }\end{array}$ \\
\hline Category of non neoplastic leslons & $\mathbf{n}(\%)$ \\
Mild Chronic Gastritis & $22(27.5)$ \\
Chronic Active Gastrits & $15(18.5)$ \\
Chronic Superficial Gastrits & $9(11.25)$ \\
Being Gastric Ulcer & $4(5)$ \\
Granulomatous Gastritis & $1(1.25)$ \\
Hyperplastic Polyp & $3(3.75)$ \\
\hline
\end{tabular}

Dysplasia and metaplasia were however not present in the cases of gastritis. Chronic superficial gastritis was noted in nine $(11.25 \%)$, benign gastric ulcer was noted in four $(5 \%)$, hyperplastic polyp was noted in three $(3.75 \%)$ and granulomatous gastritis was noted in one $(1.25 \%)$. Amongst the neoplastic lesions all were malignant lesions, while most malignant lesions were adenocarcinoma $19(23.75 \%)$ followed by seven $(8.75 \%)$ cases of squamous cell carcinoma (Table 2 ).

\begin{tabular}{|c|c|c|c|}
\hline $\begin{array}{l}\text { Caregory of neo- } \\
\text { plastic lessions }\end{array}$ & Site & n (\%) & $\begin{array}{l}\text { Age range } \\
\text { (years) }\end{array}$ \\
\hline $\begin{array}{l}\text { Moderately differ- } \\
\text { entiated adeno- } \\
\text { carcinoma }\end{array}$ & Antum & $15(18,75)$ & $45-77$ \\
\hline $\begin{array}{l}\text { Well differenti- } \\
\text { ated adenocarci- } \\
\text { noma }\end{array}$ & Antum & $2(2.5)$ & $57-67$ \\
\hline $\begin{array}{l}\text { poorly differenti- } \\
\text { ated adenocrci- } \\
\text { noma }\end{array}$ & & 1 1.25) & 75 \\
\hline $\begin{array}{l}\text { Early gastric car- } \\
\text { cinoma }\end{array}$ & Antum & 1 1.25) & 63 \\
\hline $\begin{array}{l}\text { moderately } \\
\text { differentiated } \\
\text { squamous cell } \\
\text { carinoma }\end{array}$ & Antum & $7(8.75)$ & $52-76$ \\
\hline
\end{tabular}

Almost all neoplastic lesions were from antrum except for seven cases of squamous cell carcinoma taken from gastro esophageal junction.

\section{DISCUSSION}

Biopsy sampling of the gastric mucosa at diagnostic endoscopy provides useful information which helps in the diagnosis of various lesions. The most common indications for gastric biopsy are; to detect various types of gastritis along with evidence of Helicobacter pylori status, gastric ulcers and different tumors.

The present study has shown preponderance of nonneoplastic gastric lesions with $27.5 \%$ of mild chronic gastritis and $18.75 \%$ cases of chronic active gastritis. Helicobacter pylori was positive in $16.25 \%$ cases out of $18.75 \%$ cases of chronic active gastritis. H. pylori negative chronic gastritis cases could be due to intake of proton pump inhibitors prior to endoscopic biopsy or failure to see Helicobacter pylori in the tissue specimens.

Majority of our cases of chronic active gastritis (16.25\%) also showed $\mathrm{H}$. pylori infection and correlated with presence of neutrophils and lymphocytes in the lamina propria which showed similar results with the study by Afzal et al. ${ }^{6}$ Similar study by Schultz et al, showed $87 \%$ cases having chronic active gastritis, and 
$87.7 \%$ gastric biopsies were positive for H.pylori. ${ }^{7}$ In other series overall infectivity of $\mathrm{H}$. pylori was $83 \%$ in adult population undergoing $\mathrm{Gl}$ endoscopy for various reason. ${ }^{8,9}$ In present study biopsy included majority of representative tissues from antral mucosa. It is suggested that careful examination of four specimens (two antral and two corpus) has a high probability of establishing the correct $\mathrm{H}$. pylori status. Corpus biopsies are particularly valuable for yielding positive results after treatment. ${ }^{10,11} \mathrm{H}$. pylori associated chronic active gastritis also revealed atrophic changes in six ( $7.5 \%)$ cases, similar with the study by Afzal et al. which showed atrophic and intestinal metaplastic changes in $47(10 \%)$ out of 472 cases. $^{6}$

In present study, gastric biopsy revealed malignant tumors in $26(32.5 \%)$ cases which were clinically also suspected of tumors. A diagnostic yield of over $95 \%$ has been claimed for endoscopic gastric biopsy undertaken for a suspected neoplasm especially in the advanced stages. In a study done by Plummer et al showed adenocarcinoma as a common gastric malignancy, common location being the antrum (56\%) which is comparable with our study. ${ }^{12}$

Early gastric carcinoma was one (1.25\%) and carcinoma at gastro-esophageal junction was seven $(8.75 \%)$ in our study which are similar with the study by Plummer et al where early gastric carcinoma $(2.8 \%)$ and tumors at gastro-esophageal junction four $(1.8 \%)$ out of total 216 cases. $^{12}$

Gastric carcinoma is uncommon before the age of 40 years, but thereafter, its incidence increases progressively with increasing age, peaking in the seventh decade of life. ${ }^{13}$ The data reflects this global trend for most part, with the disease in our patients being commonest between the ages of 45 to 77 years.

This is a single centered study, to draw clearer picture on this, a multicenter study is needed.

\section{CONCLUSIONS}

A variety of non-neoplastic and neoplastic lesions were reported in the present study across a wide age and site distribution. Mild chronic gastritis was the commonest lesion noted in non noeplastic lesions and adenocarcinoma was the commonest neoplastic lesion in the endoscopic gastric biopsies. All above findings correlated well with that of similar studies.

\section{REFERENCES}

1. Owen DA. Gastritis and carditis. Mod Pathol. 2003 Apr;16(4):325-41.

2. Dixon MF, Genta RM, Yardley JH, Correa P. Classification and Grading of Gastritis:The updated sydney system. Am J SurgPathol. 1996;20(10):1161-79.

3. Blackstone MO. Endoscopic Interpretation. Normal and pathologic appearances of the Gastrointestinal tract. New York: Raven Press; 1984. p. 13-5.

4. Suvakovic Z, Bramble MG, Jones R etal. Improving the detection rate of early gastric cancer requires more than open access gastroscopy: a five year study. Gut. 1997;41(3):308-13.

5. Barr H. Endoscopic screening for upper gastrointestinal malignancy. Westaby D, Lombard M. In: Gastrointestinal Endoscopy. Martin Dunitz Ltd (UK): Therapeutic; 2002. p. 54-6.

6. Afzal S, Ahmad M, Mubarik A, Saeed F, Rafi S, Saleem N, et al. Morphological spectrum of gastric lesions - endoscopic biopsy findings. Pak Armed Forces Med J. 2006;56(2):143-9.
7. Schultz M, Duarte I, Chianale J, et al. Frequency and histopathologic features of chronic gastritis in 300 patients without endoscopic lesions. Rev Med Chil1. 1996;124:545 -52.

8. Qureshi H, Ahmed W, Syed S et al. Helicobacter pylori clearance and its eradication in duodenal ulcer patients. J Pak Med Assoc. 2004;54(8):63-4.

9. Zaitoum AM. Histology compared with chemical testing for urease for rapid detection of helicobacter Pylori in gastric biopsy specimen. J Clin Path. 1993;46:684-5.

10. Hunt RH. Hp and $\mathrm{pH}$ : implications for the eradication of Helicobacter pylori. Scand J Gastroenterol Suppl. 1993;196:12-6.

11. Solcia E, Villani L, Luinetti O, Fiocca R. Proton pump inhibitors, enterochromaffin-like cell growth and Helicobacter pylori gastritis. Aliment PharmacolTher. 1993;7(1):25-8.

12. Plummer JM, Gibson TN, McFarlane ME, Hanchard B, Martin A, McDonald AH. Clinicopathologic profile of gastric carcinomas at the University Hospital of the West Indies. West Indian Med J. 2005 Dec;54(6):364-8.

13. Fuchs CS, Mayer RJ. Gastric Carcinoma. N Engl J Med. 1995;333:32-41. 